\title{
Plant molecular pharming 2012 and beyond
}

\author{
Michael E. Horn
}

Published online: 4 February 2012

(C) Springer-Verlag 2012

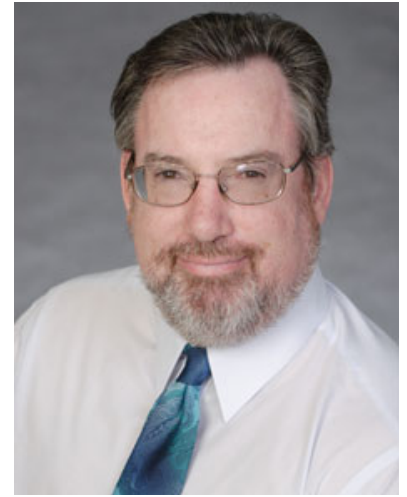

Michael E. Horn, Ph.D.

Editor-in-Chief and Special Issue Editor

It is with significant pride that we bring to you this special issue on Plant Molecular Pharming. We prefer the term "Pharming" rather than "Farming" because all of the proteins and secondary products are destined to be introduced into the human health marketplace. This is an area of science that is near and dear to my heart, as I have worked for two plant molecular pharming companies, Prodigene and Phyton Biotech (NJ), both unfortunately closed now. But Prodigene was the first plant molecular pharming company to launch not one but three products to the marketplace: GUS, TrypZein ${ }^{\circledR}$ (trypsin), and AproliZein ${ }^{\circledR}$ (aprotinin), all produced in corn seed (Horn et al. 2004).

Invitations to contribute to this Special Issue went out to the scientific community in mid-May and the response was

M. E. Horn ( $\square)$

Cibus US LLC, San Diego, CA, USA

e-mail: mhornpcr@gmail.com outstanding. Many manuscripts were submitted and put through our rigorous review system.

In total, we have six review articles and six original papers. Lico et al. (2012) reviews the use of plants for the production of human peptides. Our own Reviews Editor Ralf Reski, along with his colleague Eva Decker, provides an overview on glycosylation in moss which he grows in bioreactors (Decker and Reski 2012). Prof. Reski handled all of the reviews in this Special Issue except his own. He has my sincere gratitude. Cai et al. (2012) review the recovery of important secondary compounds from plant cell in suspension cultures. For those of you who consider algae to be plants, the use of Chlamydomonas as a production system for recombinant proteins is reviewed by Rosales-Mendoza et al. (2012a). HIV vaccine candidates from plants are reviewed by Rosales-Mendoza et al. (2012b). Finally, Hiwasa-Tanase et al. (2012) give a synthetic view of their efforts to produce the taste-modifying protein miraculin in transgenic tomato.

As for original papers, Kan Wang and colleagues have described the production of transgenic maize with cholera toxin B subunit (Karaman et al. 2012). Masumura and colleagues describe the production of human growth hormone in rice seeds but that production interfered with storage protein production (Shigemitsu et al. 2012). Kwon et al. (2012) investigate the absorption of transgenic protein to the vessel surface with plant suspension cultures. The problems and perspectives of producing antigen proteins in plants are described by Siegert et al. (2012). Lai and Chen (2012) describe the challenges of producing virus-like Norwalk virus capsid particles under Good Manufacturing Practice conditions. Finally, Pniewski et al. (2012) provide details on the expression in plants and processing for medium and large surface antigens for the purpose of preparing an oral vaccine. 
Thank you to all the authors, editors and reviewers without whom this Special Issue would not have been possible. Also, many thanks to Dr. Bettina Hahne, our hard-working Managing Editor and Ms. Diba Lingasamy for her excellent work behind the scene in producing this issue.

\section{References}

Cai Z, Kastell A, Knorr D, Smetanska I (2012) Exudation: an expanding technique for continuous production and release of secondary metabolites from plant cell suspension and hairy root cultures. Plant Cell Rep (in this issue). doi:10.1007/s00299-011-1165-0

Decker EL, Reski R (2012) Glycoprotein production in moss bioreactors. Plant Cell Rep (in this issue). doi:10.1007/s00299-011-1152-5

Hiwasa-Tanase K, Hirai T, Kato K, Duhita N, Ezura H (2012) From miracle fruit to transgenic tomato: mass production of the tastemodifying protein miraculin in transgenic plants. Plant Cell Rep (in this issue). doi:10.1007/s00299-011-1197-5

Horn ME, Woodard SL, Howard JA (2004) Plant molecular farming: systems and products. Plant Cell Rep 22:711-720

Karaman S, Cunnick J, Wang K (2012) Expression of the cholera toxin B subunit (CT-B) in maize seeds and a combined mucosal treatment against cholera and traveler's diarrhea. Plant Cell Rep (in this issue). doi:10.1007/s00299-011-1146-3

Kwon J-Y, Lee K-H, Cheon S-H, Ryu H-N, Kim SJ, Kim D-I (2012) Adsorptive loss of secreted recombinant proteins in transgenic rice cell suspension cultures. Plant Cell Rep (in this issue). doi: 10.1007/s00299-011-1184-x
Lai H, Chen Q (2012) Bioprocessing of plant-derived virus-like particles of Norwalk virus capsid protein under current Good Manufacture Practice regulations. Plant Cell Rep (in this issue). doi:10.1007/s00299-011-1196-6

Lico C, Santi L, Twyman RM, Pezzotti M, Avesani L (2012) The use of plants for the production of therapeutic human peptides. Plant Cell Rep (in this issue). doi:10.1007/s00299-011-1215-7

Pniewski T, Kapusta J, Bociąg P, Kostrzak A, Fedorowicz-Strońska O, Czyż M, Gdula M, Krajewski P, Wolko B, Płucienniczak A (2012) Plant expression, lyophilisation and storage of HBV medium and large surface antigens for a prototype oral vaccine formulation. Plant Cell Rep (in this issue). doi:10.1007/ s00299-011-1223-7

Rosales-Mendoza S, Paz-Maldonado LMT, Soria-Guerra RE (2012a) Chlamydomonas reinhardtii as a viable platform for the production of recombinant proteins: current status and perspectives. Plant Cell Rep (in this issue). doi:10.1007/s00299-011-1186-8

Rosales-Mendoza S, Rubio-Infante N, Govea-Alonso DO, MorenoFierros L (2012b) Current status and perspectives of plant-based candidate vaccines against the human immunodeficiency virus (HIV). Plant Cell Rep (in this issue). doi:10.1007/s00299011-1194-8

Shigemitsu T, Ozaki S, Saito Y, Kuroda M, Morita S, Satoh S, Masumura T (2012) Production of human growth hormone in transgenic rice seeds: co-introduction of RNA interference cassette for suppressing the gene expression of endogenous storage proteins. Plant Cell Rep (in this issue). doi:10.1007/ s00299-011-1191-y

Siegert M, Pertl-Obermeyer H, Gadermaier G, Ferreira F, Obermeyer $\mathrm{G}$ (2012) Expression of the major mugwort pollen allergen Art v 1 in tobacco plants and cell cultures: problems and perspectives for allergen production in plants. Plant Cell Rep (in this issue). doi:10.1007/s00299-011-1199-3 